\title{
Transatlantica
}

Revue d'études américaines. American Studies Journal

\section{Creating a new iconicity: an interview with Catherine Opie}

Juliette Mélia

\section{(2) OpenEdition}

1 Journals

\section{Electronic version}

URL: https://journals.openedition.org/transatlantica/6430

DOI: 10.4000/transatlantica.6430

ISSN: $1765-2766$

\section{Publisher}

Association française d'Etudes Américaines (AFEA)

\section{Electronic reference}

Juliette Mélia, "Creating a new iconicity: an interview with Catherine Opie", Transatlantica [Online], 1 । 2013, Online since 04 January 2014, connection on 01 February 2023. URL: http://

journals.openedition.org/transatlantica/6430 ; DOI: https://doi.org/10.4000/transatlantica.6430

This text was automatically generated on 1 February 2023.

\section{(c) (i) (9)}

Creative Commons - Attribution-NonCommercial-NoDerivatives 4.0 International - CC BY-NC-ND 4.0 https://creativecommons.org/licenses/by-nc-nd/4.0/ 


\title{
Creating a new iconicity: an interview with Catherine Opie
}

\author{
Juliette Mélia
}

\section{EDITOR'S NOTE}

Merci à Catherine Opie de nous avoir autorisés à reproduire gracieusement ses photographies.

1 A few days ago I got in touch with Regen Projects, gallery and agent of the famous California-based photographer, Catherine Opie, in order to obtain an interview with her. A long and rather casual chat ensued:

Juliette Mélia: I'd like to start with apologies for having first tried to contact you directly via Facebook, I realize now it was not really appropriate. Is it a sign of the times, that the boundaries between public and private are more blurred than before, is it the idea behind your series In and Around Home and your self-portraits? 
Oliver in a Tutu

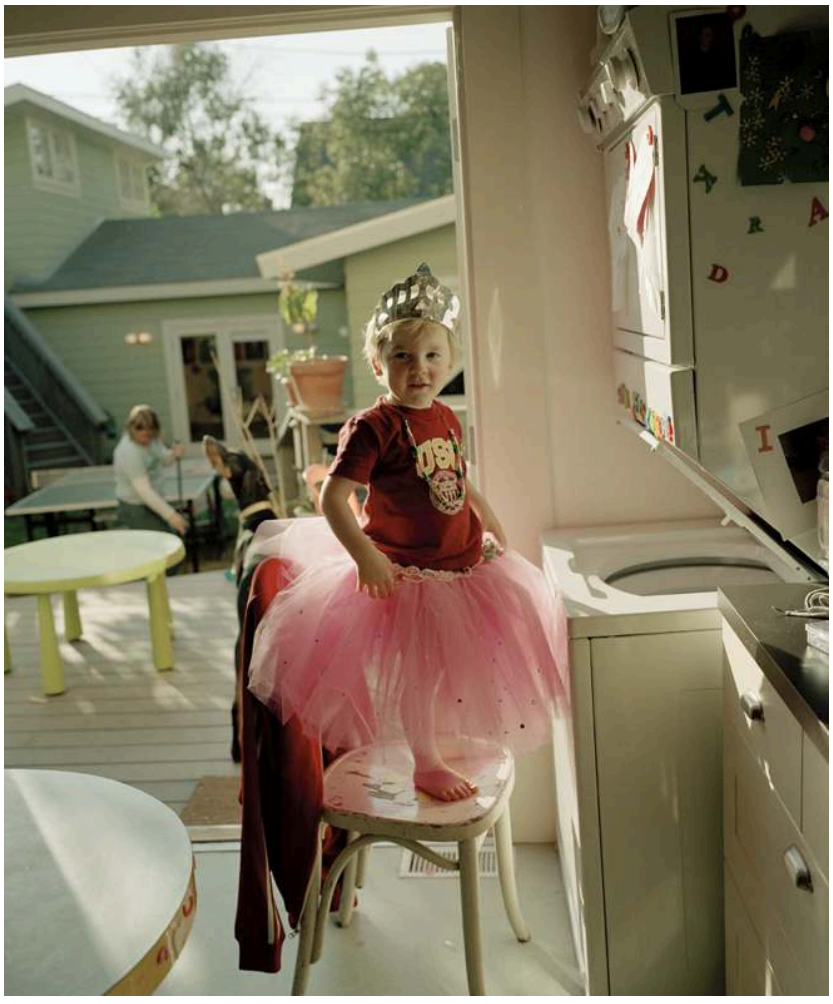

Catherine Opie, Oliver in a Tutu, In and Around Home, 2004, C-print, 24 × 20 inches (c) Catherine Opie, Courtesy of Regen Projects, Los Angeles 




Catherine Opie, Self Portrait, November 2, 2004, In and Around Home, 2004, C-print, 20 x 16 inches (c) Catherine Opie, Courtesy of Regen Projects, Los Angeles

Catherine Opie: I'm more interested in the idea of the private in relationship to a public politics versus those lines of purely public or private. I've always been interested in the idea that politics come first so you have to put yourself out there in an honest way in terms of representation, living as we do in such an extremely homophobic society.

JM: So do you suppose that as a public figure you have a different or displaced intimacy?

CO: I think that a good work has an intimacy to it that can hopefully go beyond oneself, at least that's what I'm trying to do in my work anyway. But when I first made the self-portraits I had no public life, at that point I was not a public figure, it was afterwards that I became a public figure, when I started launching the shows.

JM: In the context of what we imagine from here a conservative, even puritan America, have you been criticized for your art and life choices? If so, in what terms, are you sensitive to that?

CO: For the most part I have not been criticized in relationship to my images even if I've been misunderstood or if assumptions have been put upon me because of my work. So a lot of people who early on would see the self-portraits, when they'd interview me they'd go "oh, you're so nice!" What did you think? A lot of people assume what my personality might be because of the work that I'd made. 
JM: Have you had students or parents who were worried about your message on sexuality, who might be more sensitive to the sexual content of some of your photography than to its aesthetics?

CO: Maybe those are private home conversations but nobody has ever come forward and said "I don't want you working with my kid." Fortunately that hasn't happened!

Sometimes I worry though. You know I have an 11-year-old son. When he first started in kindergarten I was really worried about what the parents would think about us as the only out queer family of the school. So I think there is a lot of internal homophobia in conversations that go on in my head more so than actually in the public response. I definitely internalize the puritanical nature of America. [laughs]

JM: Can we still talk of puritanical America in this light?

2 CO: Well, it exists, we see it every day in our media. Prop 8 happened in California, and that was huge. We had the right to marry and then that right was put forth to voters and it was voted down. Now the Supreme Court is hearing it. It's always out there but it seeps in with me in different ways even when it's not directly aimed at me.

Untitled \# 1 (March 4th, 2009)

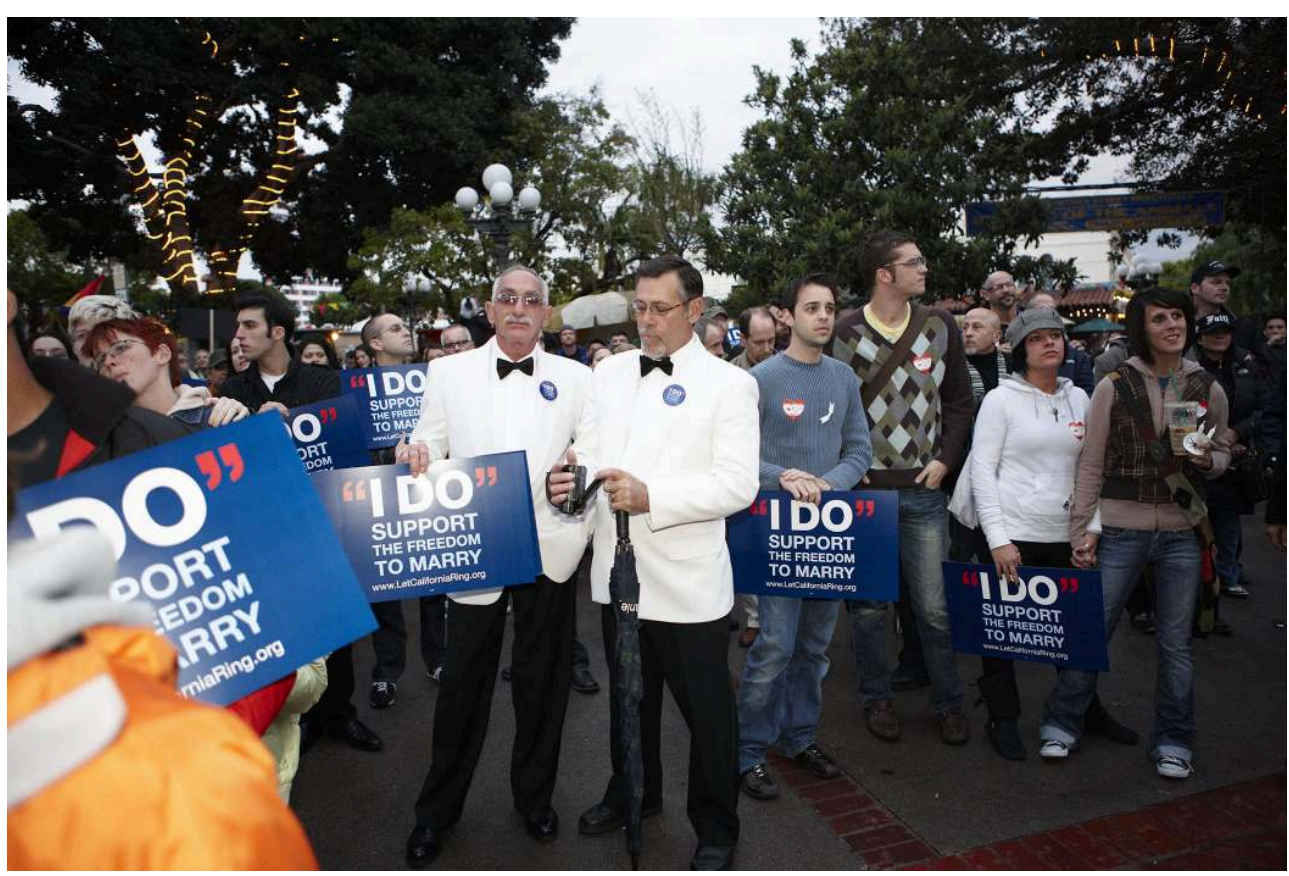

Catherine Opie, Untitled \# 1 (March 4th, 2009), 2009, Inkjet print, 37 1/2 × 50 inches

(c) Catherine Opie, Courtesy of Regen Projects, Los Angeles

At the moment there are two similar things happening, there is Prop8, which is a California-based thing which went to the Supreme Court, and then there is DOMA, the Defense of Marriage Act, voted in by Clinton in 1996, both under scrutiny right now. Most people think they will be reversed because public opinion in America is at its highest point at the moment in wanting marriage equality. Saying that, I'm not gonna be convinced until it actually happens, I'm in a wait and see kind of moment.

JM: Same here! In France at the moment we're in the middle of a kind of Prop8 moment, the government is trying to implement same-sex marriage but there is a lot of fiercely 
violent protest. Do you have a message of support for the people on the street who are protesting right now?

CO: You have to stay public, you have to stay clear in your message, and that's what I do with my work. If you're not there fighting for equal rights the risk is to keep slipping backwards. The momentum in relationship to other countries that have equality rights in relationship to marriage and so forth is in our favor. Eventually if you believe in the notion of democracy it has to encompass equality.

JM: Democracy, it's as simple as that!

CO: It's very simple. And it's not their frikking business who you love, you know, get over it... [laughs]

JM: You know that I'm very much into self-portraits, they are the subject of my research, and I think you expect a lot of questions about them from me. Are you proud or a little bit weary that people keep asking you about your self-portraits fifteen years after they've been done?

\section{Self-portrait / Cutting}

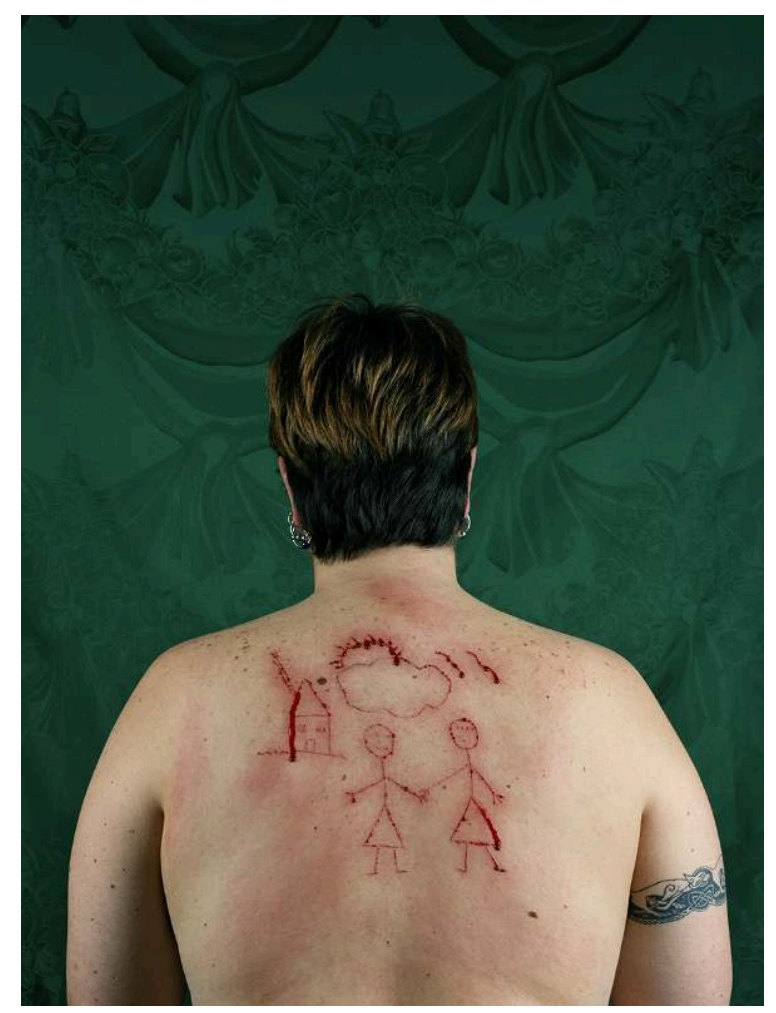

Catherine Opie, Self-portrait / Cutting, 1993, C-print, 40 × 30 inches (c) Catherine Opie, Courtesy of Regen Projects, Los Angeles 
Self-portrait / Pervert

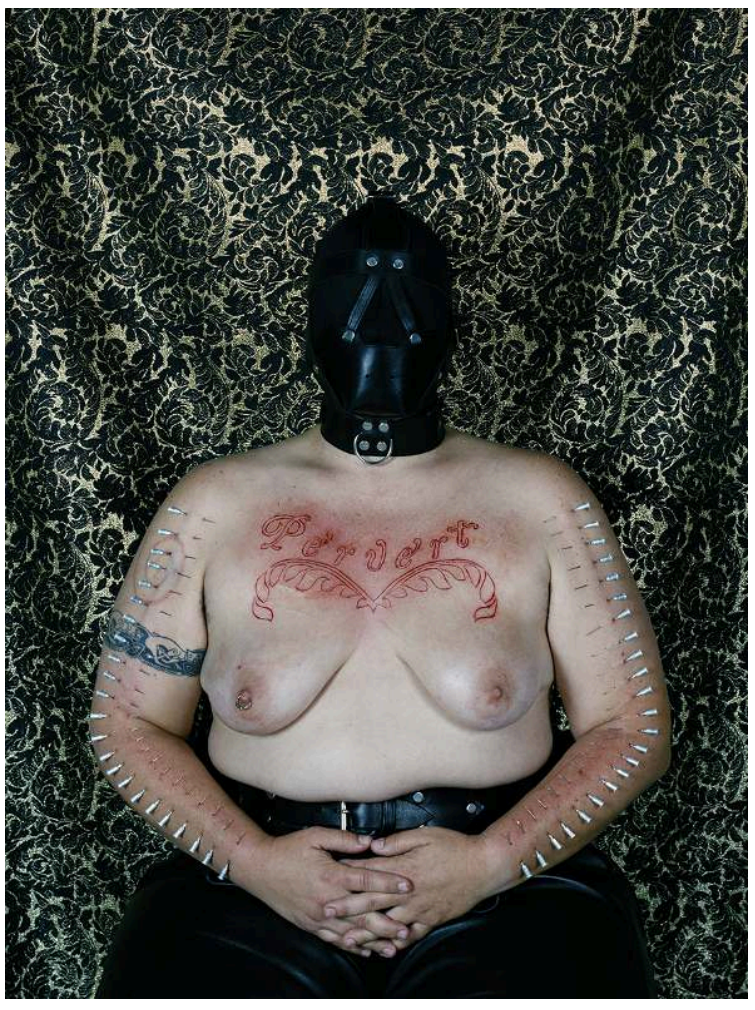

Catherine Opie, Self-portrait / Pervert, 1994, C-print, 40 × 30 inches (c) Catherine Opie, Courtesy of Regen Projects, Los Angeles 


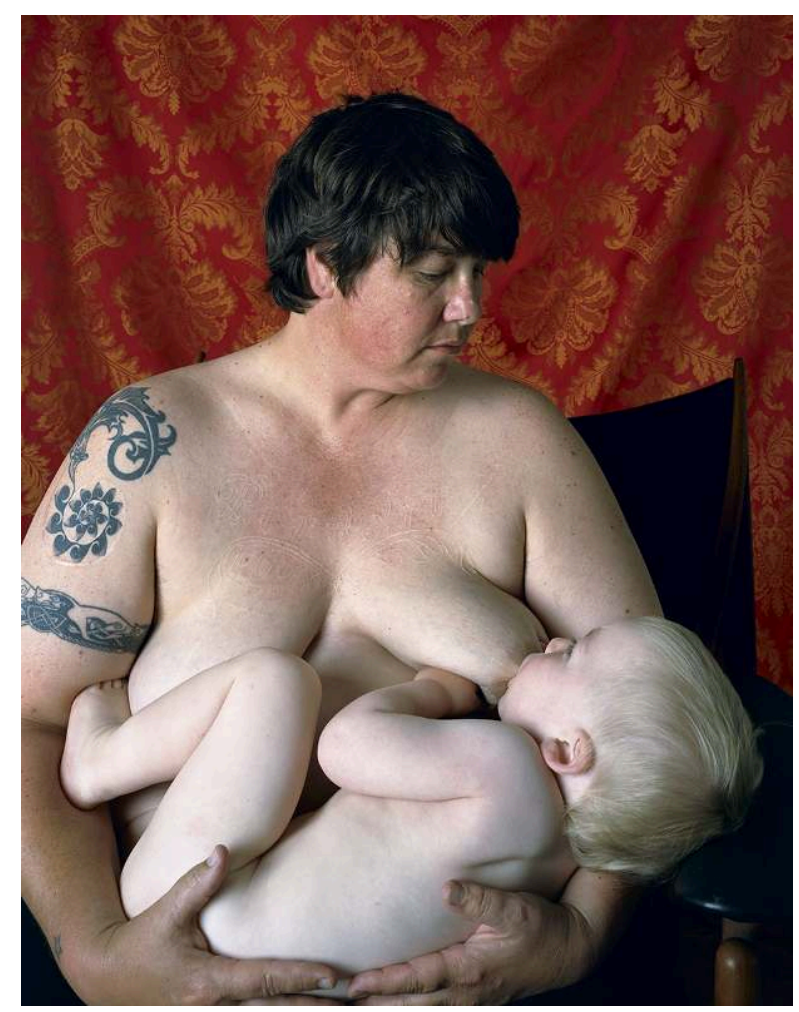

Catherine Opie, Self-portrait / Nursing, 1994, C-print, 40 × 30 inches (c) Catherine Opie, Courtesy of Regen Projects, Los Angeles

CO: It's more like twenty years!

JM: I know, that was me trying to be polite.

CO: The thing is they became very iconic and they became very important to a lot of people. I'm very touched by that, that I could make something that created such an impact in a lot of people's lives, and that I was willing to be that public with my body, my ideology, to put them up in the world. This is what artists do: they challenge and create discourse that create history in relationship to their ideas about their work. So no, I'm not really tired of it. I think it's interesting that so much circles back to it. I'm glad that I made work that have all these young queers come up to me and thank me, that they saw my show when they were kids and that had changed the way that they felt about themselves. That's when they understood that they would be ok in the world, and that's very moving, that always sends tears to my eyes.

JM: An artist, a photographer's self-portraits, sometimes work like a code, they have a special status because they give a sense of perspective, for example we know that when you photograph queerness it's from a queer perspective, and then it shows in your landscapes and your photos of houses, which really posit you as outside. Do you think selfportraits give a more political weight to your other series, do you also consider them as special?

CO: My work is about being able to create a different kind of iconography or an iconic way of beginning to look, in some ways, at wider politics, ideas of how we look at the world and community, our relationship to landscape and place. I think that it's important to be both inside the studio and outside the studio because I don't want to be a singular identity and I am interested in representing all the ideas that I have, not 
only in relationship to my politics of being queer and those ideas of representation. So I think that some people have tried to talk about all the work in terms of a queer perspective but I don't necessarily see it that way. I look at my work in relationship to my own ideas as an artist and some of them are definitely in relationship to gender politics but it's also one of the things I like about the way that I moved in and out of bodies of work throughout my life. There are also genuine observations of other things that I'm interested in. My work has also been moved by several things: the language of art, the language of photography, the current political situation, and many other things.

$\mathrm{JM}$ : Can you take me through the circumstances of the shooting of your self-portraits? What comes first, the background material or the idea that it will support? How do you find someone you trust enough to hold the scalpel? Were they public? Were they filmed?

CO: Both of them are filmed and I've lost both films. I moved back and forth from New-York in a year and there was a box that had all my videotapes and documentation in it. I know that Self-Portrait/Cutting, the very first one that was videotaped, is completely gone. But there are people who have a copy of Selfportrait / Pervert, I've been trying for the last three years to get somebody to send me a copy and nobody will. My friends are flaking out on me!

The first self-portrait was done in my living room in Los Angeles. It was an idea that I had after a really tumultuous break-up of my first domestic relationship. A year after I broke up I was still in a state of "Woe is me, I'm never gonna find a home and all these things that I really long for." Part of it was really working out those ideas of longing, like what it is for us to long. Also what it is for us in terms of a representation of what a child might make at school, which would be surprising to any kindergarten teacher: two stick-figure girls holding hands. I now have children from queer families who write me all the time and tell me how important this image is. Also teachers will say: "Oh my god, I have a kid who made two stick-figure girls holding hands with a skirt just like the cutting on your back." It really did come out of this place of: "What do we think of domesticity, what is it about longing." The portrait is also very optimistic because the sun is coming out of the clouds. I would hope that there is mostly optimism in most of my work.

That one was done in 1993 and my good friend, a really amazing artist named Judie Bamber who had never done a cutting before did the cutting. She practiced on a chicken breast! She was super, super scared but she is a really precise and amazing painter. I wanted a friend who wasn't part of my SM community to do it, I wanted it to be tentative. I like how there are areas that are cut deeper and other areas that aren't cut as much, there is more of a scratching of the surface versus the cutting.

Pervert was done by a professional, Raylinn Galine. It was done with a roomful of people, about fourteen people, and it was done in San Francisco. I had set up a studio to make portraits and I decided to Self-portrait / Pervert that summer. I had two really good friends from Body Manipulation who did professional piercings, Melissa and Joe. They put the needles in first. Then I sat in the seat after doing the set up of the $4 \times 5$ camera, because I knew it was going to be too hard to do it after going through all of that, having all the needles put in and the cutting done. I knew I wanted the cutting to just be red. I didn't want it to be dripping like Self-portrait/Cutting. I wanted it almost like stenciled, you know. Raylinn went through it, it took, the whole thing, needles and cutting, about an hour and fifteen minutes. It was intense, I was 
breathing... But the hardest part wasn't necessarily the cutting. It was afterwards, with the spraying the alcohol on the chest and patting it down to where the blood was not dripping anymore. That cutting was perfectly done because she was a professional, and it still remains on my body as you saw with Self-portrait/Nursing. The depth of it, everything about it was perfect, because I wanted it to be a permanent piece, while the first self-portrait is not a permanent piece, there is not any trace of this piece left on my body. I wanted that kind of perfection to happen.

In terms of the background, I wanted the green fabric background to reference seventeenth century painting, but I have a fruit bowl over my head, the fabric has this fantastic fruit. That's another way of queering the image, the use of a background that has a little bit of humor in it. You're looking at this juxtaposition of cutting of two stick figures, you know, women holding hands, with this comic fruit bowl over my head in the fabric.

Pervert has the design of the fabric in the skin as well. I wanted gold and black and I knew that I was going to wear a hood because I knew that after that kind of body work, there would be a kind of dislocation within my face anyway. I didn't want the self-portrait to be about my face, I wanted it to be about what was on my body, the existence of that word and what that word meant. I would inscribe it on my body and that would be where the politics lie, not in a look in my eyes.

JM: What about your titles? Do you choose them instinctively or do you put a lot of work in them?

CO: They're pretty quick. Most of the things I do I do pretty quickly. Well actually the work takes a long time to make, I spend a lot of time trying to make highly aestheticized work, I'm really interested in how the sublime operates within my portraiture, I try to use the idea of beauty to make the people stop and just look at my community versus just the assumptions that they have of my community. It's carried out throughout the work, I can't help being a formalist, that's a big strong place that I come from as an artist. But the titles are just really matter-of-fact, for the most part. They just describe what it is.

JM: Yes, but instead of Self-portrait / Nursing, you could have chosen Self-portrait / Mother, which would have been an even more straightforward description.

CO: Nursing was important yes, I love the idea that I nursed for a year and a half. Oliver was just past a year. My mother didn't really nurse me and nursing is so funny, people have such issues about it. I'd be out in public and basically start feeding my baby and people would go: "What are you doing?" Even though it was 2002, there were still some people shocked by the act of it, which didn't make any sense to me.

I like the idea of "Self-portrait / Nursing" better that of "Self-portrait / Mother." Because there is the assumption that I am the mother but maybe within ideas of butch identity, I'm not just the mother. Mother was too feminizing for me, even though nursing is an utterly womanly thing and I'm very proud of being a mum, but a lot of my butch friends really freaked out when I was pregnant, they were all: "What are you doing being pregnant? I don't get it!", and I was: "What? Yeah, I'm pregnant, I can be pregnant." It was really challenging for them because so many of my friends switched from female to male, the butch identity always had to come out as something very masculine. I was always very comfortable with being in both places, having that binary, not being just femme, therefore supposed to have children. There 
are many femmes who don't want to be pregnant! It was interesting how our butch friends were a bit freaked out at my idea of pregnancy. So when they'd come over I would just take out my boob and shoot them with milk and that would totally freak them out. [laughs]

$\mathrm{JM}$ : Well if they think of you as Bo, they see you only as your Bo identity, I can understand that. (Bo is Opie's male alter ego, the masculine persona she sometimes enacts.)

CO: Exactly, they see me as Bo!

JM: In the series Domestic, you have a strong sense of secrecy, the lesbian couples are portrayed in homes or enclosed gardens. How did you break the secrecy, how did you basically meet the couples?

CO: I bought an RV, a recreational vehicle, and spent three and a half months on the road. I would go to different towns, either because I had friends there or because the location was interesting. I would go to the one and only lesbian bar and have the DJ announce what I was doing. That's how I made my way across the country trying to make the body of work. But I'm curious about the secrecy, what you mean about the secrecy? Let's go into that a little bit more.

$\mathrm{JM}$ : They are inside, at home, you have the sense that their houses are a way for them to protect themselves from the potentially hostile outside world, probably more so than for any straight couple.

CO: That's interesting, I never really thought about it that way.

One of the things I always think about is who I want to have conversations with, what does it mean to create history related to a history that is already present, the need to add a conversation to a given situation, because something is not being represented, something is left out of the telling of the story. So there was a very important show at that moment, with a curator of photography, Peter Galassi, called Pleasures and Terrors of Domestic Comfort. It was one of the zeitgeist ideas following up from Steichen's Family of Men, but pushing it up to a contemporary representation of domesticity. And in that there wasn't any representation of queer domesticity, of women or men living together. Tina Barney was a really important artist at this period, she was shown in that exhibition as well as a number of other people. What happened was that as they totally left out the images of the gay community, I decided to use the same kind of tools as Barney, an $8 \times 10$ camera. I bought an RV and we had the perfect American road trip dream, me and my dog, I just went forth and created this body of work to create a conversation with that history that was happening throughout the nineties of imaging domesticity. So I never thought of them as secret. I always thought of them as as present as the other domestic photographs that I had seen, finally a representation of a lesbian home.

JM: It can also be an imposed or de facto secrecy. In mainstream culture we don't necessarily think about gay couples.

$\mathrm{CO}$ : Yeah, but there's no reason why we shouldn't.

JM: So how did it make you feel when you realized there were no queer couples in this exhibition? Angry, sorry?

CO: No, not necessarily angry, more that it needed some kind of correction. Pervert was made as an angry piece. That is one of the only things that I made that came out of this really intense place of being angry, even though it is a very refined piece. I wasn't angry when I made Domestic, I just wanted to make sure that there was 
somebody who was also trying to create history in relationship to the scale of the images and what the images did.

You may remember that in Domestic there is a still life of a washer and dryer. So when I went around the country lecturing to people, I would basically say: "And this is a lesbian washer and dryer" as a joke, because every washer and dryer is a washer and dryer, it's the same thing. But in the South when I said it was a lesbian washer and dryer at a lecture, this one woman asked what specifically was a lesbian washer and dryer. And I said: "Well it's the exact same washer and dryer as you have, that's the point, it's a joke you know. It is a joke that you guys assume that we are so utterly different but there is no difference, we have beds, we use the same washers and dryers, the same kitchen knives and so on." So that is what the body of work was coming out of.

JM: I know that your Domestic series were quite staged.

CO: Yeah, they have to be with an $8 \times 10$ camera, you can't shoot casually with such a camera.

JM: Does this change a lot depending on the different series, whether you're outside, in the studio, do you talk a lot to your models, is it different when they are friends or strangers?

Idexa

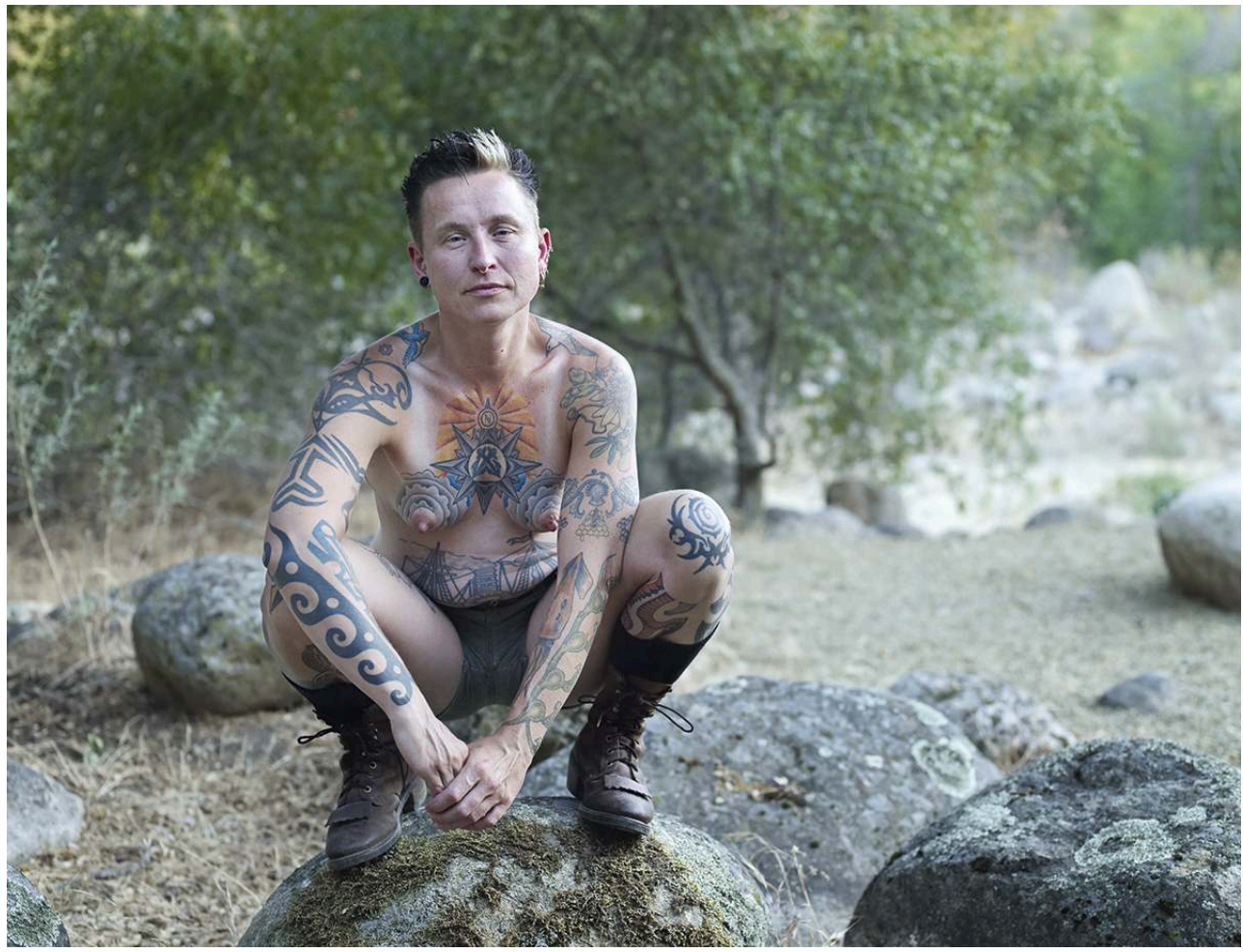

Catherine Opie, Idexa, 2008, C-print, 37 1/2 x 50 inches

(c) Catherine Opie, Courtesy of Regen Projects, Los Angeles

CO: I'm not a big talker when I photograph, I don't play music, I don't chat away a lot, I'm quietly instructing people how I want to see them, I try to think how the photo is going to look, I might say things like "pick up your hand this way, turn your head this way..." But I'm not chatting anybody up. I feel that it's a very quiet moment between us. But you should ask one of my friends what's it's like to be photographed by me. 
JM: I'd like that! As far as the background is concerned, there is quite a radical change in your latest series.

co: It's all black, yeah.

Installation View of Catherine Opie at Regen Projects, Los Angeles

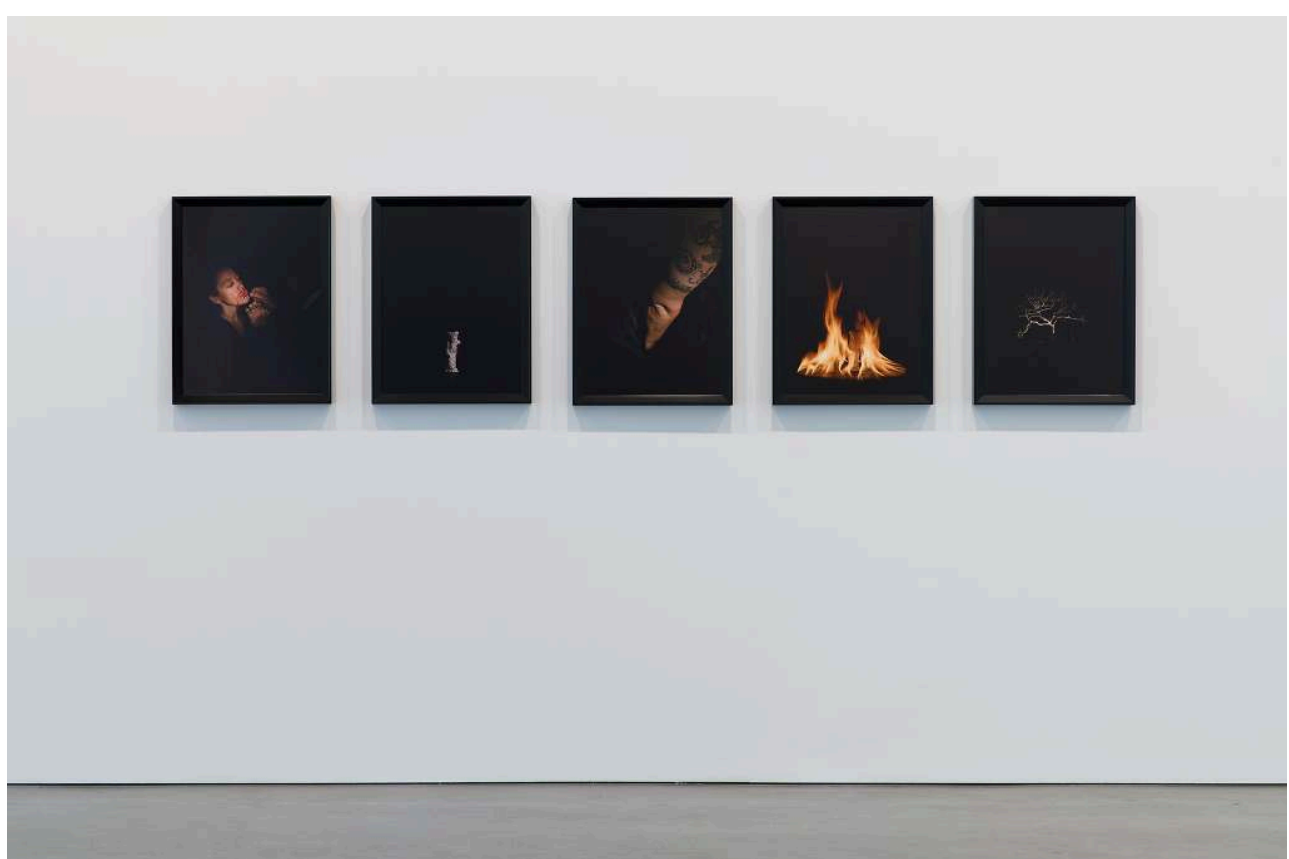

Brian Forrest, Installation View of Catherine Opie at Regen Projects, Los Angeles, Feburary 23 - March 29, 2013

Photo Credit: Brian Forrest 


\section{Julie \& Pigpen}

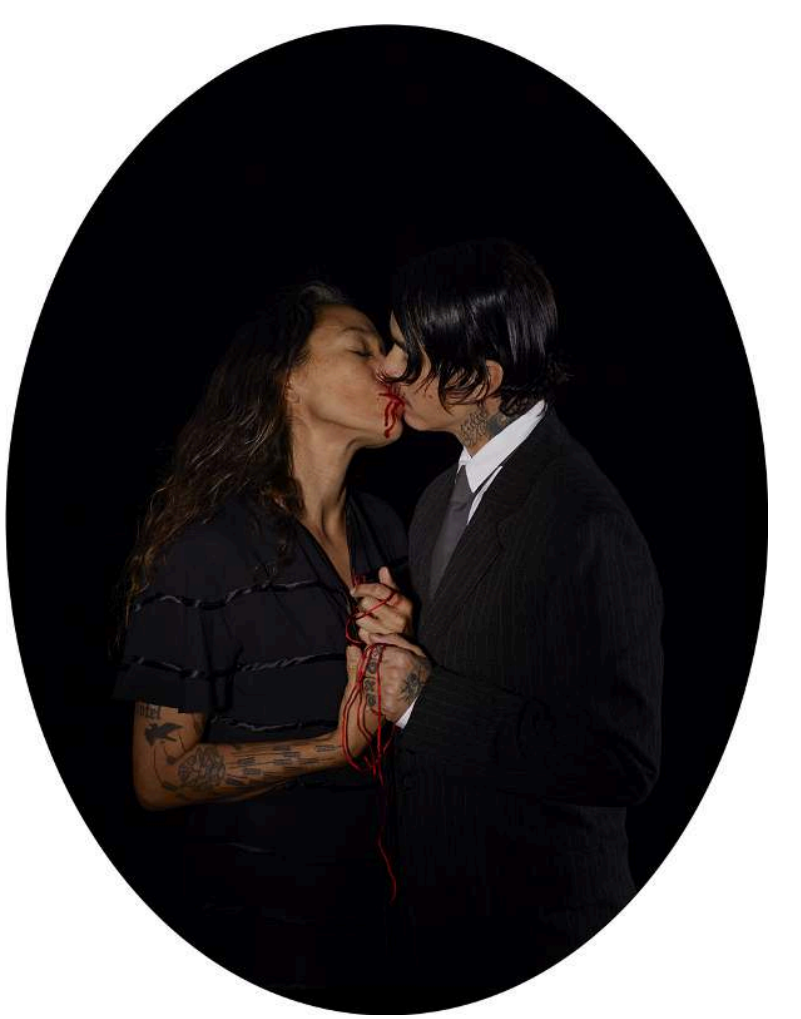

Catherine Opie, Julie \& Pigpen, 2012, Pigment print, 50 × 30 inches (c) Catherine Opie, Courtesy of Regen Projects, Los Angeles 


\section{Guinevere}

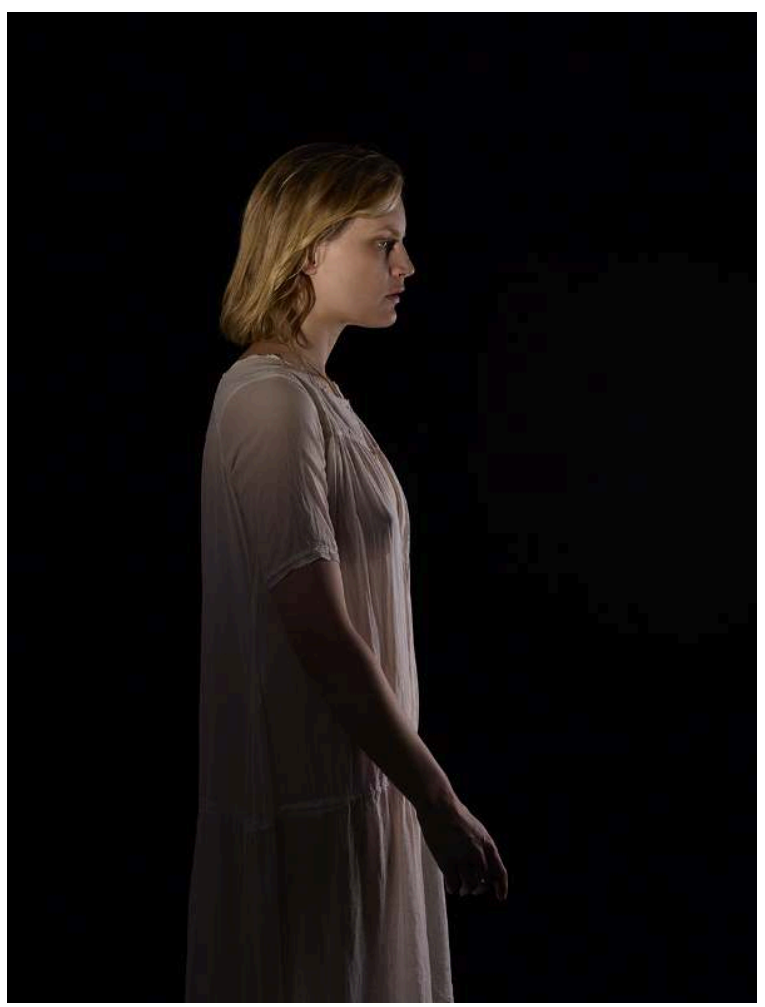

Catherine Opie, Guinevere, 2012, Pigment print, 33 × 25 inches

(c) Catherine Opie, Courtesy of Regen Projects, Los Angeles

JM: Do you think it has a sobering effect to pose in it and to photograph someone against a black background, compared to the gold yellow or vibrant colours of the early series, Being and Having or Portraits?

CO: It's totally sobering! [laughs] Those figures emerging out of darkness are a very internal body of work. My other works are about my politics of representation, this one is more about the politics of being a fifty-two year-old woman in menopause [laughs]. I think they're very deep, they're very intensely psychological, allegorical, and I had not really played in that territory before.

JM: It shows I think! They have a very introspective feel.

CO: One of my friends said on seeing the work: "Oh! So Cathy you grew up!" It's my grown up work! [laughs]

$\mathrm{JM}$ : Talking of backgrounds, do you plan on using more textile backgrounds, like in the Selfportraits and Dyke series, or is this a finished work?

CO: No, you never know, they could come back again, I never can really think about it till I'm trying to figure out the next body of work. I would imagine so, I like fabric, I like textiles, I've got a really good fabric hook-up. The amazing fabric place called "Diamond Foam and Fabrics" in Los Angeles has given me all my fabric for free and they get a little print of everything I've made since the beginning. I have great fabric options to go there. For now everything still needs to come out of black, then we'll see what I do with portraits, I have no idea. 
If you are interested in fabric, I also photographed Elizabeth Taylor's closet, you can go crazy over the fabrics in Elizabeth Taylor's closet, with the clothes hanging the exact same way for decades.

JM: If I'm not mistaken, there is fabric in the photo of your arm in the latest series.

Arm

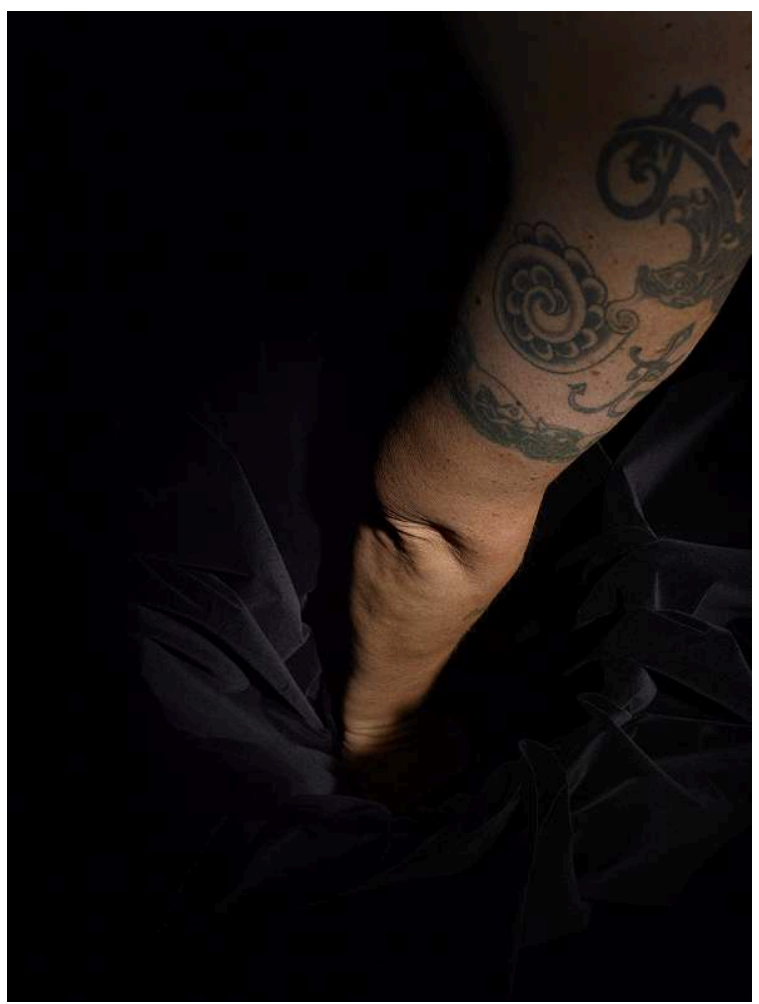

Catherine Opie, Arm, 2012, Pigment print, 24 × 18 inches

(c) Catherine Opie, Courtesy of Regen Projects, Los Angeles

CO: It's the black fabric of the background I'm photographing on, that I've just crunched up. You can see the fabric in the bonsai tree too. But those are the only pieces that you can really read the background material that I'm using.

JM: When you choose to photograph your arm, why do you choose this body part, did you see it as meaning something special?

CO: [laughs] If the piece had a title...which it doesn't, but if it had a title it would be "Fisting the Void." That's what I was thinking when I was making it. Not only putting my arm into it but pulling out myself from the inside. We did a lot with that bucket, Heather my assistant and I. We put mud in it, but the arm was the photograph that I liked the best. It came out of a dream that I had, a dream of me pulling myself out of a black hole. The arm here is basically that gesture of either fisting the black hole or pulling myself out of the black hole, it works both ways.

JM: I was anticipating that you would see your arm as a sign of both strength and tenderness, because we all have in mind the image of your powerful and very tender arms in Self-portrait / Nursing, so it's funny that the two elements you choose to describe what you arm and this gesture mean to you are also in sharp contrast. There is also contrast in a political situation I would like you to discuss: in 2008 people talked a lot about the election of Barack Obama as the beginning of a new era, an era that would be more equal and now 
we have a sense of disappointment sometimes. Did you share the enthusiasm, and do you also share the disappointment?

CO: I completely shared the enthusiasm. I think a lot about the disappointment. A lot of my friends likewise, who are obviously leftists and Liberals like myself are really disappointed in him. I feel a little bit differently in that there is so much incredible opposition against him in relationship with this country. He's trying to do as much as he can without completely blowing up everything that he could begin to build. Having universal healthcare really happened for the first time in this country and whether or not that will last will be very interesting. But those kinds of legacies are really important first steps to that idea of what is a democracy. I think he inherited a horribly messed up country. I'm saddened to see him more of a war-time president than I had thought that he would be, I thought he would be a little bit cleaner around Afghanistan and drones and stuff about what America goes through. I'm very sad that all of the work he's doing around guns in this country is not passing. A bill to reduce the right to bear arms was voted down just yesterday, a bill that implemented very small changes too, not a bill to get rid of all the guns in America all of a sudden. It makes you wonder how we can make it so that there is not so much gun violence in this country.

Compared to who we could have as president, I feel pretty good still about having him as a leader, I feel inspired by him, by his optimism and the thoughtfulness that he tries to lead our nation with. We're the same age, we were both born in 1961, it makes me feel like we have a lot in common. At times I'm disappointed, but you know it's a disappointing country to live in with the ultra-conservative movements.

JM: What about his cultural policies?

CO: He is one of the first presidents to really put contemporary art in the White House. I have four images hanging in the White House in the private quarters.

JM: Can we know which ones? Is it your photos of the inauguration? 


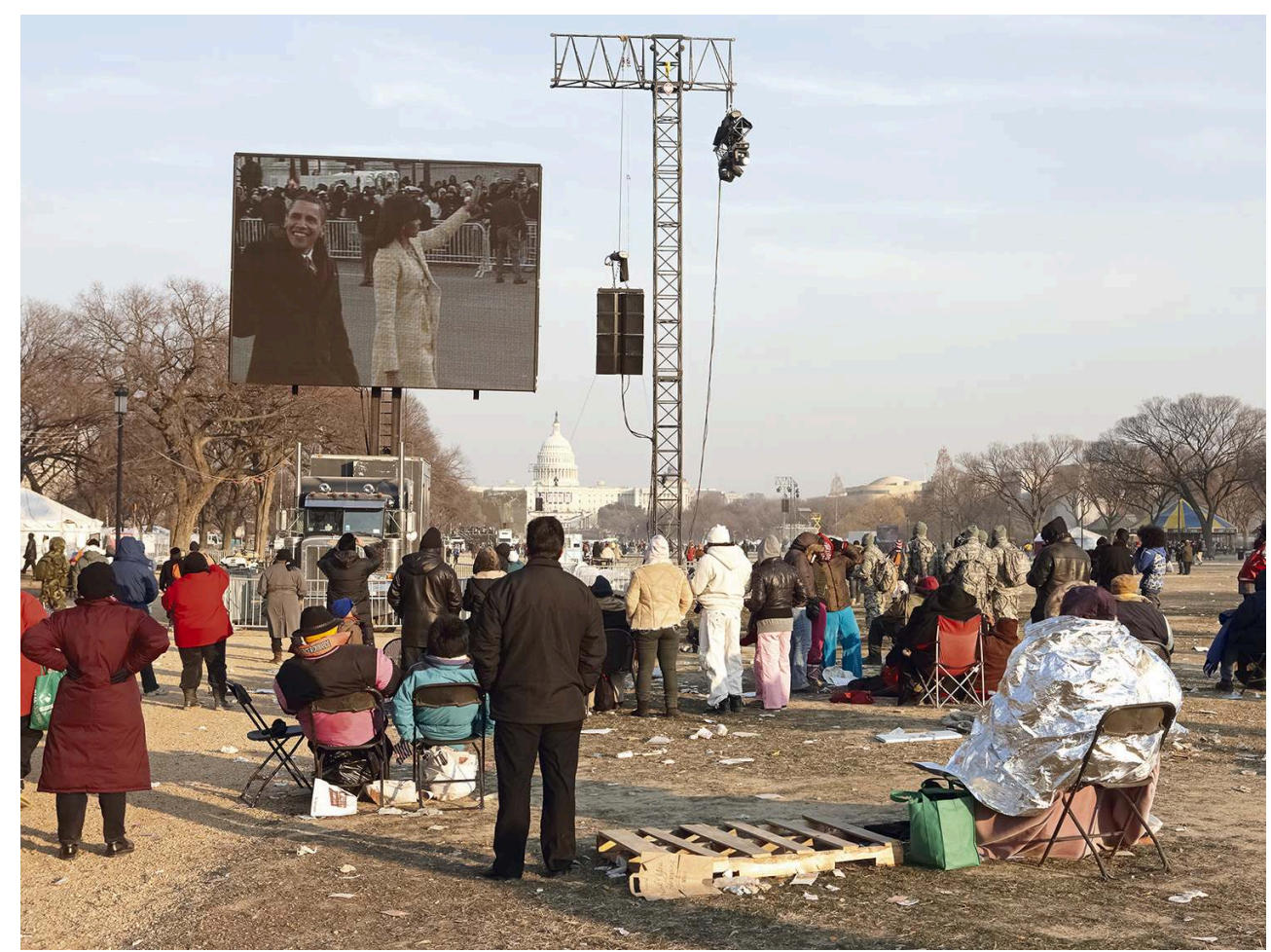

Catherine Opie, Untitled \#1 (Jan. 20th, 2009), 2009, C-print, 37.5 x 50 inches

(c) Catherine Opie, Courtesy of Regen Projects, Los Angeles

CO: It's heavily curated, it's not the self-portraits. [laughs] It's the four seasons of Lake Michigan in Chicago.

Lake Michigan, Fall, Winter, Spring and Summer

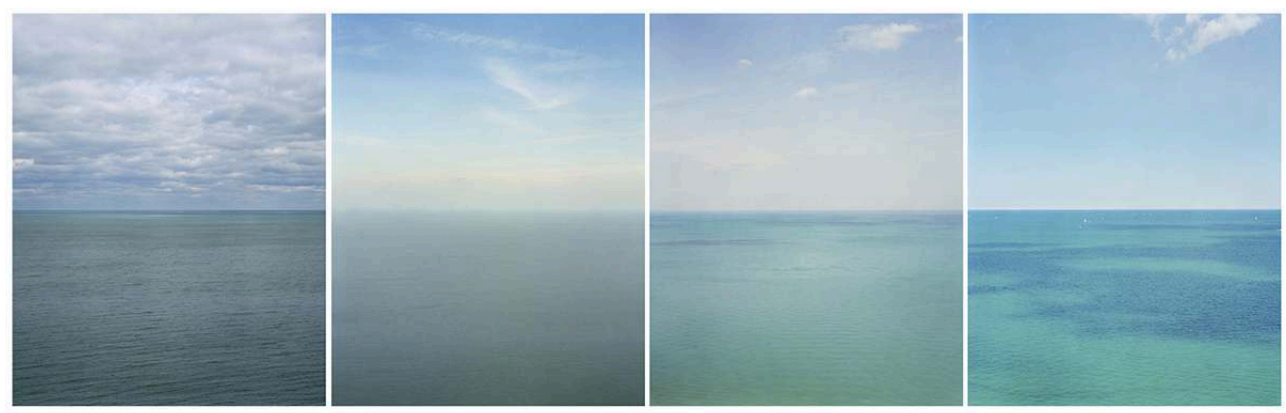

Catherine Opie, Lake Michigan, Fall, Winter, Spring and Summer, 2004-2005, four C-prints, 50 × 40 inches (c) Catherine Opie, Courtesy of Regen Projects, Los Angeles

He tries to encourage art and cultural ideas, but it is very hard because he is faced with having to do extreme budget cuts to be able to balance the budget. He put more money in the art in terms of the National Endowment of the Arts, the institution which helps our museums and so forth, but it's still very little because of all the things that had to be cut. But cultural policies have been abysmal for years in this country, and still there are so many amazing artists. 
JM: Now that we're getting to the end of this interview, do you feel that there is a question I should have asked and did not? Is there a question you always expect and is never asked?

CO: I'm trying to think. I've been asked a lot of questions. Is there anything that I always ask about being asked? Will I be redundant about saying asked so many times? I often wonder why people always start with the early works. I understand that they have the biggest impact but I feel that sometimes people miss the nuances of what's going on in the other bodies of work. I guess that's more of a general feeling than necessarily a specific question...

JM: Your work is so varied and rich that it's difficult to discuss it in its entirety. Like me, people must tend to focus on what interests them most at the risk of not giving a complete idea of it.

CO: Yes, I guess it must be that...

JM: Finally, a lot of people who are going to read this interview are very interested in books and literature, they would probably be interested in your literary tastes. Do you have a pillow book, what book are you reading at the moment?

CO: I'm always reading! I read Zadie Smith recently. I'm reading George Saunders' new novel right now. But in terms of people who influence my work through reading and ideas, it's usually women writers. Joan Didion, I've been reading Didion since I was seventeen years old and will follow everything that she writes. Also Rebecca Solnit, based in California, who talks about ideas in history and politics and landscape, she wrote an amazing book called The Field Guide to Getting Lost, which I often recommend to people and students to read. She's a really amazing woman and writer. I have just finished Charles Schultz's biography. I often read biographies, Steve Jobs' biography, or of other people who didn't really have a college education but did amazing innovative things. I was always a real Peanuts fan when I was a kid, I read every single Peanut comic strip, I grew up with Charles Schultz as an important figure, he was a kind of comics philosopher. I was curious to see how he would be represented in the book. I really like biographies.

JM: Well, I'll write yours if you want.

CO: That's good, I like that!

\section{AUTHOR}

JULIETTE MÉLIA

Université Diderot - Paris 7 